NBER WORKING PAPER SERIES

\title{
OPENNESS CAN BE GOOD FOR GROWTH: THE ROLE OF POLICY COMPLEMENTARITIES
}

\author{
Roberto Chang \\ Linda Kaltani \\ Norman Loayza \\ Working Paper 11787 \\ http://www.nber.org/papers/w11787 \\ NATIONAL BUREAU OF ECONOMIC RESEARCH
1050 Massachusetts Avenue
Cambridge, MA 02138
November 2005
}

We gratefully acknowledge the valuable support of the World Bank's Poverty Reduction and Economic Management Network. We are also grateful to César Calderón, Rómulo Chumacero, Marco Cipriani, Mieke Meurs, Romain Ranciere, Klaus Schmidt-Hebbel, Luis Servén, Vicente Tuesta, Roberto Zhaga, and seminar participants at George Washington University, the World Bank, the Central Bank of Chile, the Central Bank of Peru, the Tenth Conference of Dynamics, Growth, and International Trade, and the Paris Meetings of the Latin American and Caribbean Economic Association for valuable comments and suggestions. Finally, Chang thanks the hospitality and financial support of Princeton University. The views expressed in this paper are those of the authors, and do not necessarily reflect those of the World Bank, their Boards of Directors, or the countries they represent. The views expressed herein are those of the author(s) and do not necessarily reflect the views of the National Bureau of Economic Research.

(C2005 by Roberto Chang, Linda Kaltani, and Norman Loayza. All rights reserved. Short sections of text, not to exceed two paragraphs, may be quoted without explicit permission provided that full credit, including (C) notice, is given to the source. 
Openness Can be Good for Growth: The Role of Policy Complementarities

Roberto Chang, Linda Kaltani, and Norman Loayza

NBER Working Paper No. 11787

November 2005

JEL No. E61, F13, F43, O40

\begin{abstract}
This paper studies how the effect of trade openness on economic growth depends on complementary reforms that help a country take advantage of international competition. This issue is illustrated with a simple Harris-Todaro model where output gains after trade liberalization depend on the degree of labor market flexibility. In that model, trade protection may ameliorate the problem of underemployment (and underproduction) in sectors affected by labor market distortions; hence trade liberalization unambiguously increases per capita income only when labor markets are sufficiently flexible. We then present some panel evidence on how the growth effect of openness depends on a variety of structural characteristics. For this purpose, we use a non-linear growth regression specification that interacts a proxy of trade openness with proxies of educational investment, financial depth, inflation stabilization, public infrastructure, governance, labor-market flexibility, ease of firm entry, and ease of firm exit. We find that the growth effects of openness are positive and economically significant if certain complementary reforms are undertaken.

\author{
Roberto Chang \\ Rutgers University \\ Department of Economics \\ 75 Hamilton Street \\ New Brunswick, NJ 08901 \\ and NBER \\ chang@econ.rutgers.edu \\ Linda Kaltani \\ American University \\ Norman Loayza \\ World Bank
}




\section{OPENNESS CAN BE GOOD FOR GROWTH: The Role of Policy CoMPlementarities}

\section{INTRODUCTION}

Ever since Ricardo's critique on the Corn Laws to the current debate on globalization, few topics in economics have been more hotly contested as the importance of international trade openness for economic development. The arguments in favor of openness are well known and date back at least to Adam Smith's analysis of market specialization. Openness promotes the efficient allocation of resources through comparative advantage, allows the dissemination of knowledge and technological progress, and encourages competition in domestic and international markets. Standard trade theory captures the gains from openness as movements towards the production possibilities frontier. To this income-level effect, recent theoretical models add a long-run growth effect when the areas of specialization promoted by trade enjoy increasing returns to scale, as illustrated in the endogenous growth models of Young (1991), Grossman and Helpman (1991), Eicher (1993), and Lee (1993).

Opposing arguments are not too hard to build. If market or institutional imperfections exist, openness can lead to sub-utilization of human and capital resources, concentration in extractive economic activities, or specialization away from technologically advanced, increasing-return sectors. Grossman and Helpman (1991) and Matsuyama (1992) provide theoretical models where a technologically backward country specializes in a non-dynamic sector as a result of openness, thus losing out on the benefits of increasing returns. Underlying these models there is an imperfection in contracts or in financial markets that makes people obey a myopic notion of comparative advantage. Sachs and Warner (1995, 1999) develop a model where specialization in extractive, natural-resource sectors prevents a country from the technological progress that eventually leads to long-run growth. In this case, the underlying imperfection is an institutional weakness that encourages natural-resource depletion for quick gains appropriated by certain groups in society. Rodríguez and Rodrik (2000) review the theoretical arguments as to why openness can be detrimental to developing countries; they do so in a second-best 
context, in which trade liberalization is the policy lever --and the eventual culprit-- while market and institutional weaknesses are accepted as immanent characteristics.

The theoretical ambiguity on the effects of openness is reflected in the available empirical evidence. Some papers point to strongly positive growth effects by trade liberalization. This is the case of Dollar (1992) and Sachs and Warner (1995), who run cross-country growth regressions on composite indices of the stance of trade policy; as well as Edwards (1998), who prefers to base his positive evaluation by examining the robustness of various individual indicators of trade liberalization in cross-country growth regressions. But others, most notably Harrison (1996) and Rodriguez and Rodrik (2000) have cast doubt on the significance and robustness of the growth benefits of openness. Their critique starts with the openness measures used in practice; for instance, some purportedly openness indicators reflect general poor economic management (e.g., the black market premium) or are primarily affected by geographic characteristics (e.g., the trade volume). Other criticisms are based on econometric grounds, such as omitted-variable bias (particularly due to the exclusion of institutional and geography-related variables) and joint endogeneity bias (stemming from the effect of growth on certain policy regimes).

Recent empirical studies have addressed these criticisms by emphasizing the overtime variation in openness indicators and growth performance. (Harrison 1996 had already noted that panel studies rendered a more positive evaluation of the growth effects of openness than cross-sectional studies.) Dollar and Kraay (2004) and Loayza, Fajnzylber, and Calderón (2005) run growth regressions on panel data of large samples of countries. Both papers use indicators fo openness based on trade volumes and control for their joint endogeneity and correlation with country-specific factors through GMM methods that involve taking differences of data and instruments. This implies that, although they continue to use cross-country data, these papers favor within-country changes as the main source of relevant variation. Both papers conclude that opening the economy to international trade brings about significant growth improvements. Wacziarg and Welch (2003) arrive at a similar, though more nuanced, conclusion from a methodologically different standpoint. Using an event-study methodology --where an event is defined as a year of substantial trade policy liberalization-- they find that liberalizing countries tend to experience significantly higher volumes of trade, investment rates, and, most importantly, 
growth rates. However, in an examination of 13 country-case studies, Wacziarg and Welch find noticeable heterogeneity in the growth response to trade liberalization. Although their small sample does not allow for definite conclusions, it appears that the growth response after liberalization is positively related to conditions of political stability.

This paper starts with the observation that although opening to trade is beneficial to economic growth on average, the aftermath of trade liberalization varies considerably across countries and depends on a variety of conditions related to the structure of the economy and its institutions. A simple exercise may serve to convey this point. Figure 1 plots changes in growth rates of per capita GDP between the 1990s and 1980s versus changes in the volume of trade (as a ratio to GDP) between those two decades for a worldwide sample of 82 countries. Figure 1 has four panels; in each of them we separate the country observations according to whether they belong to the top one-third (diamonds) or bottom two-thirds (circles) of a rank distribution given by, in turn, each of the following criteria: a) secondary enrollment rates (a proxy for human capital investment); b) main telephone lines per capita (a proxy for public infrastructure); c) a subjective index of the quality of governance; and d) a de facto and de jure index of labor market flexibility. (Appendix 2 gives details on variable definitions and sources.) Each criterion used for ranking country observations is measured over the 1980s, the beginning period.

Dividing the country observations into top and bottom groups allows us to compare the corresponding slopes for the relationship between changes in trade volume ratios and changes in economic growth rates. In all panels, the OLS line described by the bottom observations is basically flat, implying no relationship between trade opening and growth improvement in the bottom groups. However, this changes for the top groups: for the top observations, the slope of the OLS line is positive and steeper than that for the bottom group. ${ }^{1}$ This clearly suggests that the empirical impact of trade opening on growth may depend on the existence and degree of distortions in non trade areas. Of course, this is quite a simple exercise and it does not control for other growth determinants (such as initial per capita GDP), does not account for joint endogeneity, and does not use all

\footnotetext{
${ }^{1}$ For the top observations according to educational investment, public infrastructure, and governance, the slope of the OLS line is significantly positive at conventional levels. The top observations according to labor market flexibility also describe a positive slope that is larger than that of the bottom group, but it is not statistically significant. The more satisfactory methods later in the paper, however, indicate that the impact of labor market reforms on the trade opening/growth relationship is in fact strongly significant.
} 
information efficiently. But more careful econometric methods are used later in the paper and confirm that the growth response to trade opening is heterogeneous, and not in random ways but in relation to specific country conditions.

This paper studies how the eventual success of openness in terms of growth performance depends on the economic and institutional characteristics that make a country able to adjust to the new conditions imposed by international competition. This idea is very general, but for concreteness our discussion starts with a simple theoretical example where the gains in output after trade liberalization depend on the degree of labor market flexibility. The example is a version of the well known Harris-Todaro model, and labor market distortions are represented by a minimum wage that applies to the formal sector of the economy. Trade restrictions are modeled as a tariff that also applies to formal sector output. In the model, trade protection may serve to ameliorate the problem of underemployment (and underproduction) in the sector affected by labor market distortions. As a consequence, trade liberalization unambiguously increases per capita income only when labor market distortions are sufficiently small. ${ }^{2}$

Our model continues the examination of commercial policy in the presence of labor-market distortions (Brecher 1974). But we regard it, more generally, as an example in the tradition of the general theory of the second best (Lipsey and Lancaster 1956). From this perspective, one should expect similar interactions between openness and complementary reforms in other areas. For instance, in the influential work of Acemoglu and Zilibotti (2001), openness (in the sense of unobstructed access to technological progress) does not lead to productivity improvements in developing countries that fail to improve their human capital (to adopt the new technologies) and to enforce intellectual property rights (to encourage the development of technologies best suited to their skill mix). Likewise, Banerjee and Newman (2004) have recently presented a model in which lack of financial development and sluggish factor mobility make poor countries lose from

\footnotetext{
${ }^{2}$ In the model the potential gains from openness are given in terms of the level of output per capita. There is no contradiction between this static treatment and our empirical emphasis on growth effects. This is so because the time horizons used in current econometric studies do not allow discriminating long-run growth effects from long-lasting transitional level effects. Moreover, the finding of conditional convergence suggests that growth impulses coming from improvements in growth determinants tend to decrease as per capita GDP increases.
} 
trade openness, as unproductive sectors are wiped out by foreign competition but the capital and labor attached to them fail to divert to more efficient uses.

We then present some cross-country empirical evidence on how the growth effect of openness depends on a variety of structural characteristics, including some that may be subject to reform. We build on the panel-data growth regressions presented in Dollar and Kraay (2004) and Loayza, Fajnzylber, and Calderón (2005). As these papers do, we use a GMM procedure that controls for endogeneity and unobserved country-specific factors in order to estimate the growth effect of openness, as well as those of other policy and nonpolicy variables. We, however, depart from those studies in that we interact the openness measure with proxies of, respectively, educational investment, financial depth, inflation stabilization, public infrastructure, governance, labor-market flexibility, and ease of firm entry and exit. Our objective for using this non-linear specification is to assess whether an increase in openness may have a growth effect that depends on country characteristics that, at least in principle, are subject to improvement through economic and institutional reforms. We find that the growth effect of openness is positive and economically significant if certain complementary reforms are undertaken. This quantitative assessment may contribute towards identifying the specific reforms that are most needed to complement a trade liberalization agenda.

The empirical growth literature offers some examples of non-linear specifications considering interaction effects. On the related topic of foreign direct investment, Borensztein, De Gregorio and Lee (1998) and Alfaro, Chanda, Kalemli-Ozcan, and Sayek (forthcoming) find that the growth effect of FDI is significantly positive only when the host country has, respectively, sufficiently high human capital and financial depth. Specifically in the analysis of growth effects of trade openness, an important antecedent of our work is the empirical study by Bolaky and Freund (2004). Using cross-country regressions in levels and changes of per capita GDP and controlling for simultaneity via external instruments, they find that trade opening promotes economic growth only in countries that are not excessively regulated. They argue that in highly regulated countries, growth does not accompany trade openness because resources are prevented from flowing to the most productive sectors and firms, and trade is likely to occur in goods where comparative advantage is actually missing. Finally, Calderón, Loayza, and Schmidt- 
Hebbel (2004) interact in their panel growth regressions a measure of openness (volume of trade / GDP) with linear and quadratic terms of GDP per capita, which they regard as proxy for overall development. They find that the growth effect of trade opening is nearly zero for low levels of per capita GDP, increases at a decreasing rate as income rises, and reaches a maximum at high levels of income. Our strategy of interacting openness with specific country characteristics is, to some extent, an attempt to decipher what lies behind the dependence of the growth effect of openness on economic reform and development.

In section 2, we present a theoretical model to illustrate the ambiguous effect of trade opening once labor-market rigidities are present. Section 3 is devoted to the empirical analysis. There, we first introduce the sample and methodology, and then we present the econometric results, illustrating them with straightforward simulations. In section 4 we offer some concluding remarks.

\section{An IlluStrative Model}

The basic idea of our work is that economic reforms need to complement each other to be effective. This general principle can be derived from several models, and indeed one can see it as a straightforward implication of the theory of the second best. But we believe that it will be useful to illustrate the principle in a concrete situation. This section does just that, in the context of a simple open economy model in the spirit of Harris and Todaro (1970).

The justly celebrated Harris-Todaro model focused on endogenous migration and unemployment in the presence of labor market distortions. In our version below, distortions in the labor market interact with tariffs or other distortions in international trade. We show that, under certain conditions, a tariff reform reduces trade-related distortions but exacerbates the labor market distortions. The implication is that the sign of the impact of trade opening on productive efficiency depends on labor market conditions. This observation provides the basis for the empirical work in later sections. 


\section{$\underline{\text { Production and Employment }}$}

Consider a static small open economy. There are two consumption goods, indexed by $i=1,2$, whose world prices are given in terms of a fixed numeraire. Both goods can be produced at home with a simple Cobb Douglas technology:

$$
Y_{i}=A_{i} L_{i}^{\alpha_{i}}, \quad i=1,2
$$

Labor is the only variable input in production. Home firms are owned by (a measure one continuum of) identical entrepreneurs, which behave competitively in product and factor markets. Profit maximization then implies that, in each productive sector $i=1,2$, the value of the marginal product of labor will be equal to the wage in that sector:

$$
\alpha_{i} A_{i} P_{i} L_{i}^{\alpha_{i}-1}=W_{i}
$$

where $0<\alpha_{i}<1, P_{\mathrm{i}}$ is the home price of good $\mathrm{i}$, and $W_{\mathrm{i}}$ is the wage prevailing in sector $\mathrm{i}$.

The price of good $\mathrm{i}$ in domestic markets, $P_{\mathrm{i}}$, may differ from its world price (henceforth denoted by $P_{\mathrm{i}}^{*}$ ) because of trade policy. In particular, if there is a tariff on imports of good $i, P_{\mathrm{i}}>P_{\mathrm{i}}{ }^{*}$. A "trade reform" is a reduction in the difference between $P_{\mathrm{i}}$ and $P_{\mathrm{i}}^{*}$.

Also, as in the classic Harris-Todaro model, wages may be different in different sectors, and there is a minimum wage in sector 1 , which is assumed to exceed the wage in sector 2:

$$
W_{1}=W_{\min }>W_{2}
$$

Note that a "labor market reform" would involve eliminating the minimum wage in sector 1 .

There are $L$ workers in this economy. Each one chooses whether to work in sector 1 or 2. Once the location decision has been made, workers cannot move from one sector to the other. The critical aspect of the Harris-Todaro model is that, in equilibrium, the number of workers that choose to locate in sector 1 will be too large for all of them to be 
employed. Hence there will be a number, which we denote by $U$, of unemployed workers in sector 1 . Assuming that jobs in sector 1 are distributed randomly among workers located in that sector, the probability that a worker in sector 1 is employed is $L_{1} /\left(L_{1}+U\right)$. As we shall see, optimal location decisions by workers imply that the expected wage in the two sectors must be the same:

$$
W_{2}=\left[L_{1} /\left(L_{1}+U\right)\right] W_{\text {min }}
$$

By definition

$$
L_{1}+L_{2}+U=L
$$

Equations (2.1)-(2.5) suffice to describe the production side of the economy. Given the minimum wage $W_{\min }$ and home prices $P_{1}$ and $P_{2},(2.1)-(2.5)$ can be solved for $Y_{1}, Y_{2}, L_{1}$, $L_{2}, U$, and $W_{2}$; this is indeed the standard discussion of the Harris-Todaro model.

To see the implications of a trade reform, we will assume that $P_{1}>P_{1} *$ initially, while $P_{2}=P_{2}{ }^{*}$. That is, initially sector 1 is protected. A trade reform, therefore, involves lowering $P_{1}$ towards the world price $P_{1}$ *.

What is the effect of lowering $P_{1}$ ? By (2.2) and (2.3), a lower $P_{1}$ must reduce employment in sector 1 : since $W_{1}$ is fixed at $W_{\text {min }}$, a fall in $P_{1}$ increases the real wage in that sector, inducing firms to hire less workers. It is easy to show that $L_{2}$ must then increase. $^{3}$

Decreasing marginal productivity of labor implies that $W_{2}$ must fall. But then we conclude, from (2.4), that $L_{1} /\left(L_{1}+U\right)$ must fall or, in other words, that the rate of unemployment in sector 1 must increase. The impact on $U$, the number of unemployed workers, is ambiguous, and depends in particular on the elasticities of labor demand (the $\alpha_{\mathrm{i}}^{\prime} \mathrm{s}$ in (2.2)).

\footnotetext{
${ }^{3}$ Suppose $L_{2}$ falls. Then, by (2.2), the wage in sector 2 must increase. By (2.4), the probability of employment in sector 1 must then increase, so $U$ must fall. But then $L_{1}, L_{2}$, and $U$ would all fall, contradicting (2.5).
} 
It should also be intuitively obvious that a lower $P_{1}$ increases distortions in the labor market: this is because real wages in the two sectors move away from each other, and hence the initial gap in marginal productivity of labor between the two sectors becomes larger.

Of course, a trade reform may have beneficial effects as well. To characterize those, and to add more precision to the analysis, it may be useful to complete the description of this economy, in particular the demand side. To do this, we will make specific assumptions about workers and entrepreneurs.

\section{$\underline{\text { Demand }}$}

The typical worker consumes a Cobb Douglas aggregate of goods 1 and 2:

$$
C=C_{1}^{\gamma} C_{2}^{1-\gamma} / \gamma^{\gamma}(1-\gamma)^{1-\gamma}
$$

If his final income is $I$, the worker will choose $C_{1}$ and $C_{2}$ to maximize $C$ subject to the budget constraint

$$
P_{1} C_{1}+P_{2} C_{2}=I
$$

The solution is straightforward: let $\mathrm{P}$ denote the minimum cost of a unit of the consumption aggregate:

$$
P=P_{1}^{\gamma} P_{2}^{1-\gamma}
$$

Then

$$
P C=I
$$

and the worker will spend a fraction $\gamma$ and $(1-\gamma)$ of his income in goods 1 and 2 , respectively. 
All workers receive a transfer $T_{W}$ from the government. In addition, each worker has one unit of time, and so his income will include his wage earned if he is employed. For simplicity, assume that there is no disutility from labor.

Finally, each worker may choose to locate in sector 1 or in sector 2 . Locating in sector 2 implies that he will earn the wage $W_{2}$ for sure. In contrast, if he chooses to locate in sector 1 , he will earn the wage $W_{\min }$ only with probability $L_{1} /\left(L_{1}+U\right)$. Assuming risk neutrality, the worker will choose the location that maximizes the expected value of income. An equilibrium in which there are workers in both sectors then requires each worker to be indifferent between locating in sector 1 and sector 2 . This is easily seen now to involve that the expected wage in both sectors be the same (equation (2.4)).

For simplicity, assume that the typical entrepreneur consumes the same aggregate $C$ of goods 1 and 2 as the typical worker. He is assumed to receive a transfer $T_{K}$ from the government, and all profits from production.

Finally, for concreteness let us assume that the government levies a tariff $P_{1}-P_{1}$ * on imports of good 1 , and no tariff on imports of good 2. The government has no other sources of revenue and transfers tariff revenues to workers and entrepreneurs. Then fiscal balance requires:

$$
\left(P_{1}-P_{1}^{*}\right)\left(C_{1}^{a}-Y_{1}\right)=L T_{W}+T_{K}
$$

where $C_{i}^{a}$ denotes total domestic consumption of good $i$.

The efficiency losses associated with the tariff are now evident. Since each domestic agent spends a fraction $\gamma$ of his income in good 1 , the same must be the case for the aggregate, so

$$
P_{1} C_{1}^{a}=\gamma\left(P_{1} Y_{1}+P_{2} Y_{2}+L T_{W}+T_{K}\right)
$$

Likewise, $P_{2} C_{2}{ }^{a}$ is a fraction $(1-\gamma)$ of aggregate income. And of course aggregate expenditure in the two goods must equal aggregate income: 


$$
P_{1} C_{1}^{a}+P_{2} C_{2}^{a}=P_{1} Y_{1}+P_{2} Y_{2}+L T_{W}+T_{K}
$$

Using (2.6) in the last equation to eliminate $L T_{W}+T_{K}$ and recalling that there is no tariff on good 2, we obtain that:

$$
P_{1}^{*} C_{1}^{a}+P_{2}^{*} C_{2}^{a}=P_{1}^{*} Y_{1}+P_{2}^{*} Y_{2}
$$

In other words, the value of domestic consumption must equal the value of production, both at world prices. Note that this relation must hold for any value of the tariff.

This perspective helps to clarify the relationship between the analysis of this model and the standard analysis of tariffs. The tariff causes a distortion in consumption, since domestic agents face the after tariff relative price $P_{1} / P_{2}$ instead of the world price $P_{1}{ }^{*} / P_{2}{ }^{*}$ when making consumption decisions. This causes them to choose a consumption bundle such that the social indifference curve is not tangent to the national budget constraint line. Also, as in the standard case, the tariff causes a distortion on the production side, since it increases the relative price of good 1 , so domestic production of good 1 is inefficiently large.

In our model, however, there is an additional distortion in the labor market, due to the minimum wage in sector 1 . This distortion pushes production of good 1 down; indeed, in the absence of the tariff, production and employment in sector 1 would be inefficiently low. A tariff in sector 1 reduces the distortion by increasing the price of good 1 and inducing firms to expand hiring in that sector.

It follows that a trade reform (a reduction of the tariff to good 1) will generally reduce consumption distortions but (assuming the minimum wage $W_{\min }$ remains in place) may increase production distortions. In this sense, the success of trade reform may depend on a complementary labor market reform. 


\section{Complementary Reforms and Productive Efficiency}

As highlighted in the previous subsection, the value of production at world prices is an adequate summary of productive efficiency in this model. Denoting that value by $Z$, it follows that

$$
Z=P_{1}^{*} Y_{1}+P_{2}^{*} Y_{2}=P_{1}^{*} A_{1} L_{1}^{\alpha_{1}}+A_{2} L_{2}^{\alpha_{2}}
$$

where we have assumed that the price of $\operatorname{good} 2, P_{2}{ }^{*}$, equals one.

Assuming again that a tariff may be imposed on good 1's imports, the impact of a change in the tariff on productive efficiency is then given by

$$
\frac{d Z}{d P_{1}}=P_{1}^{*} \alpha_{1} A_{1} L_{1}^{\alpha_{1}-1} \frac{d L_{1}}{d P_{1}}+A_{2} \alpha_{2} L_{2}^{\alpha_{2}-1} \frac{d L_{2}}{d P_{1}}=\frac{P_{1}^{*}}{P_{1}} W_{\min } \frac{d L_{1}}{d P_{1}}+W_{2} \frac{d L_{2}}{d P_{1}}
$$

The last equality follows from (2.2) and (2.3).

Equation (2.8) is useful to understand the impact of a marginal change in the tariff on $Z$. To understand its implications, assume that there are no initial trade or labor market distortions. No tariffs imply that $P_{1}=P_{1} *$ and the absence of a minimum wage implies that $W_{1}=W_{2}=W$, say. Therefore, $d Z / d P_{1}=W\left[d\left(L_{1}+L_{2}\right) / d P_{1}\right]$. But $d\left(L_{1}+L_{2}\right) / d P_{1}=0$, since labor is fully employed if there is no minimum wage in sector 1 . So $d Z / d P_{1}=0$ : the marginal impact of a tariff on productive efficiency is nil. This result is in line with conventional theory.

Now suppose that initially there is no minimum wage, so that again $W_{1}=W_{2}=W$ and labor is fully employed, but that there is a positive tariff on good 1 . The latter means that $P_{1}>P_{1} *$ and the impact of a marginal tariff change is 


$$
\frac{d Z}{d P_{1}}=W\left[\frac{P_{1}^{*}}{P_{1}} \frac{d L_{1}}{d P_{1}}+\frac{d L_{2}}{d P_{1}}\right]=W \frac{d L_{1}}{d P_{1}}\left[\frac{P_{1}^{*}}{P_{1}}-1\right]<0
$$

where the last equality follows from full labor employment. So, as expected, in the absence of a minimum wage, if there is a positive tariff on good 1 , a marginal tariff reduction will increase productive efficiency.

If initially both a tariff and a minimum wage exist, the analysis is more involved. Some algebra shows that then

$$
\frac{d Z}{d P_{1}}=W_{\min } \frac{d L_{1}}{d P_{1}}\left[\frac{P_{1}^{*}}{P_{1}}-\left\{\left(1-\alpha_{2}\right)\left(L / L_{2}\right)+\alpha_{2}\right\}^{-1}\right]
$$

By (2.2) and (2.3), $d L_{1} / d P_{1}>0$. Hence the impact of a marginal change in the tariff depends on the quantity in square brackets, which captures the opposing effects on trade distortions and labor market distortions. The term $\left\{\left(1-\alpha_{2}\right)\left(L / L_{2}\right)+\alpha_{2}\right\}^{-1}$ is less than one, so the term in brackets can be positive or negative. In other words, when distortions exist in both trade and labor markets, a marginal reduction in tariffs (keeping the labor market distortion fixed) can increase or reduce productive efficiency.

Equation (2.9) has, in fact, a straightforward interpretation. The term $P_{1} * / P_{1}$ is a measure of the tariff on good 1 imports: the larger the tariff, the smaller $P_{1} * / P_{1}$. On the other hand, the distortionary impact of a minimum wage is given by $L_{2} / L$ : the smaller this ratio, the larger the RHS of (2.9). Intuitively, the smaller the size of sector 2 , the greater the discrepancy between the marginal product of labor in sectors 1 and 2 , and the more likely it is that an increase in $P_{1}$ will help increasing efficiency, by inducing more hiring in sector 1 , where the marginal product of labor is higher.

The conclusion is that a trade reform (here, a tariff reduction) may or may not improve productive efficiency if other policy distortions remain. The outcome depends, 
intuitively, on the relative importance of trade distortions and the other policy-induced distortions.

The obvious but significant corollary is that trade liberalization will not, in general, have an unambiguous effect on productive efficiency. In this model, in fact, trade liberalization will reduce productive efficiency if the labor market distortion is pronounced, but it will increase efficiency if the labor market distortion is mild. This indicates the need to include a term for the interaction between trade opening and labor market distortions in assessing the empirical connection between trade opening and growth.

The discussion in this section has focused on the links between trade liberalization and labor market reforms, but it should be apparent that the essence of the analysis can be extended to analyze the complementarity between trade opening and other reforms. Keeping this in mind, we now turn to an empirical evaluation of the complementarity of trade reform and other reforms.

\section{EMPIRICAl ANALysis}

The objective of the empirical section is to examine how the growth effect of openness may depend on a variety of country characteristics, including some that can be changed by policy. For this purpose, we work with pooled cross-country and time-series data, focusing on comparative information from within-country changes. We start with a linear growth regression specification and then extend it to account for interaction terms between an openness measure and proxies for various country characteristics. These are educational investment, financial depth, macroeconomic price stability, public infrastructure, governance, labor-market flexibility, ease of firm entry, and ease of firm exit. We build on the panel-data growth regression literature that uses a GMM procedure to control for endogeneity and unobserved country-specific factors, as presented for example in Dollar and Kraay (2004) and Levine, Loayza, Beck (2000). Further details on the methodology are given below. 


\subsection{Sample and Regression Specification}

Our sample consists of an unbalanced panel dataset that comprises 82 countries. For each of them, the dataset includes at most 8 observations, consisting of nonoverlapping 5-year averages spanning the 1960-2000 period. The sample includes 22 developed countries and 60 developing ones. Among the latter, 18 are from Sub-Saharan Africa, 12 from Asia, 9 from the Middle East and North Africa, and 21 from Latin America and the Caribbean. Appendix 1 provides the full list of countries in the sample.

The basic regression equation to be estimated is the following

$$
y_{i, t}-y_{i, t-1}=\beta_{0} y_{i, t-1}+\vec{\beta}_{1}^{\prime} C V_{i, t}+\beta_{2} O P_{i, t}+\mu_{t}+\eta_{i}+\varepsilon_{i, t}
$$

where the subscripts $i$ and $t$ represent country and time period, respectively; $y$ is the log of GDP per capita, $C V$ is a set of control variables, and $O P$ represents trade openness; $\mu_{t}$ and $\eta_{i}$ denote unobserved time- and country-specific effects, respectively; and $\varepsilon$ is the regression residual.

As is standard in the literature, the dependent variable is the average rate of real per capita GDP growth (i.e., the log difference of GDP per capita normalized by the length of the period). The regression equation is dynamic in the sense that it includes the initial level of per capita GDP as an explanatory variable. Our measure of trade openness is the (structure-adjusted) ratio of real exports and imports to real GDP. We select the set of control variables considering both their importance as growth determinants per se and their potential for affecting the growth response of trade opening. The control set includes variables that vary both across countries and over time, as well as variables that vary only across countries (that is, assumed constant over time). Among the former, we have the average rate of secondary school enrollment to account for human capital investment, the average ratio of private credit to GDP as a measure of financial depth, the average inflation rate to account for macroeconomic price stability, and the average number of main telephone lines per capita as proxy for public infrastructure. Among the variables that vary only across-countries, we have a governance index from International Country Risk Guide (Political Risk Services), labor-market and firm-exit flexibility indices from Doing Business (the World Bank), and a firm-entry flexibility index from Doing Business (the 
World Bank) and the Index of Economic Freedom (the Heritage Foundation). Appendix 2 provides full definitions and sources of all variables used in the paper, and Appendix 3 presents basic descriptive statistics for the data used in the regressions.

We then extend the regression specification by allowing the growth effect of openness to vary with the country characteristics represented by the control set. We do this by interacting the openness measure with each of the control variables in turn. The regression equation with an interaction term is the following,

$$
y_{i, t}-y_{i, t-1}=\beta_{0} y_{i, t-1}+\vec{\beta}_{1}^{\prime} C V_{i, t}+\beta_{2} O P_{i, t}+\beta_{3} c v_{i, t} * O P_{i, t}+\mu_{t}+\eta_{i}+\varepsilon_{i, t}
$$

where $c v$ represents one of the control variables in particular. We interact openness with the control variables one at a time in order to both simplify the interpretation of the results and not to overextend the parameter requirements on the data.

The interpretation of the coefficients on the time-varying variables and on their interaction term with openness is straightforward. However, the interpretation of coefficients related to the variables that are constant per country requires some explanation. In linear regression models, they are well captured by the country-specific effect and, in general, would not be incorporated into the regression specification. In our case, however, we need to include them in the regression in order to analyze their interaction with openness. The coefficients on the constant variables themselves cannot be identified unless we have additional information on their relationship with the countryspecific effect or are willing to make assumptions about it. Nevertheless, in order to complete the information set, we include them in the regression as explanatory variables on their own whenever their respective interaction with openness is analyzed. In order to avoid confusion, we do not report the estimated coefficients on the constant variables themselves but only the coefficients on their respective interaction terms.

\subsection{Estimation Methodology}

The growth regression presented above poses some challenges for estimation. The first is the presence of unobserved period- and country-specific effects. While the inclusion of period-specific dummy variables can account for the time effects, the common methods 
of dealing with country-specific effects (that is, within-group or difference estimators) are inappropriate given the dynamic nature of the regression. The second challenge is that most explanatory variables are likely to be jointly endogenous with economic growth, so we need to control for the biases resulting from simultaneous or reverse causation. The following paragraphs outline the econometric methodology we use to control for countryspecific effects and joint endogeneity in a dynamic model of panel data.

We use the generalized method of moments (GMM) estimators developed for dynamic models of panel data that were introduced by Holtz-Eakin, Newey, and Rosen (1988), Arellano and Bond (1991), and Arellano and Bover (1995). These estimators are based, first, on differencing regressions or instruments to control for unobserved effects and, second, on using previous observations of explanatory and lagged-dependent variables as instruments (which are called internal instruments).

After accounting for time-specific effects, we can rewrite equations 3.1 or 3.2 as follows:

$$
y_{i, t}=\alpha y_{i, t-1}+\vec{\beta}^{\prime} X_{i, t}+\eta_{i}+\varepsilon_{i, t}
$$

To eliminate the country-specific effect, we take first differences of equation 3.3:

$$
y_{i, t}-y_{i, t-1}=\alpha\left(y_{i, t-1}-y_{i, t-2}\right)+\beta^{\prime}\left(X_{i, t}-X_{i, t-1}\right)+\left(\varepsilon_{i, t}-\varepsilon_{i, t-1}\right)
$$

Note that by differencing we also eliminate the information provided by the variables that are constant over time.

The use of instruments is required to deal with the likely endogeneity of the explanatory variables and the problem that, by construction, the new error term, $\varepsilon_{i, t}-\varepsilon_{i, t-1}$, is correlated with the lagged dependent variable, $y_{i, t-1}-y_{i, t-2}$. The instruments take advantage of the panel nature of the data set in that they consist of previous observations of the explanatory and lagged-dependent variables. Given that it relies on past values as instruments, this method only allows current and future values of the explanatory variables to be affected by the error term. Therefore, while relaxing the common assumption of 
strict exogeneity, our instrumental-variable method does not allow the $\mathbf{X}$ variables to be fully endogenous.

Under the assumptions that the error term, $\varepsilon$, is not serially correlated and that the explanatory variables, $\mathbf{X}$, are weakly exogenous (that is, the explanatory variables are assumed to be uncorrelated with future realizations of the error term), the GMM dynamic panel estimator uses the following moment conditions:

$$
\begin{aligned}
& E\left[y_{i, t-s} \cdot\left(\varepsilon_{i, t}-\varepsilon_{i, t-1}\right)\right]=0 \quad \text { for } s \geq 2 ; t=3, \ldots, T \\
& E\left[X_{i, t-s} \cdot\left(\varepsilon_{i, t}-\varepsilon_{i, t-1}\right)\right]=0 \quad \text { for } s \geq 2 ; t=3, \ldots, T
\end{aligned}
$$

for $s \geq 2$ and $t=3, \ldots, T$. Although in theory the number of potential moment conditions is large and growing with the number of time periods, $T$, when the sample size in the crosssectional dimension is limited, it is recommended to use a restricted set of moment conditions. In our case, we work only with the first acceptable lag as an instrument; that is, for the regression in differences we use only the twice-lagged level of the corresponding variable.

The GMM estimator based on the conditions in 3.5 and 3.6 is known as the difference estimator. Notwithstanding its advantages with respect to simpler panel data estimators, the difference estimator has important statistical shortcomings. Alonso-Borrego and Arellano (1999) and Blundell and Bond (1997) show that when the explanatory variables are persistent over time, lagged levels of these variables are weak instruments for the regression equation in differences. Instrument weakness influences the asymptotic and small-sample performance of the difference estimator toward inefficient and biased coefficient estimates, respectively. ${ }^{4}$

To reduce the potential biases and imprecision associated with the usual difference estimator, we use a new estimator that combines the regression in differences and the regression in levels into one system (developed in Arellano and Bover, 1995, and Blundell and Bond, 1997). The instruments for the regression in differences are the same as above.

\footnotetext{
${ }^{4}$ An additional problem with the simple difference estimator involves measurement error: differencing may exacerbate the bias stemming from errors in variables by decreasing the signal-to-noise ratio (see Griliches and Hausman, 1986).
} 
For the regression in levels, however, the instruments are the lagged differences of the corresponding variables. These are appropriate instruments under the following additional assumption: although the levels of the right-hand-side variables may be correlated with the country-specific effect in equation 3.3, the differences of these variables are not. This assumption results from the following stationarity property,

$$
\begin{aligned}
& E\left[y_{i, t+p} \cdot \eta_{i}\right]=E\left[y_{i, t+q} \cdot \eta_{i}\right] \text { and } \\
& E\left[X_{i, t+p} \cdot \eta_{i}\right]=E\left[X_{i, t+q} \cdot \eta_{i}\right] \text { for all } p \text { and } q
\end{aligned}
$$

for all $p$ and $q$. The additional moment conditions for the second part of the system (the regression in levels) are: $:^{5}$

$$
\begin{aligned}
& E\left[\left(y_{i, t-1}-y_{i, t-2}\right) \cdot\left(\eta_{i}+\varepsilon_{i, t}\right)\right]=0 \\
& E\left[\left(X_{i, t-1}-X_{i, t-2}\right) \cdot\left(\eta_{i}+\varepsilon_{i, t}\right)\right]=0
\end{aligned}
$$

Note that in the levels regression, the variables that are constant over time are not eliminated; however, there are no available instruments for them based on either their own lagged changes (since they are constant) or the lagged changes of the time-varying variables (because if these changes are uncorrelated with the unobserved country-specific effect, they are also likely to be uncorrelated with the observed constant variables).

We thus use the moment conditions presented in equations 3.5, 3.6, 3.8, and 3.9 and employ a GMM procedure to generate consistent and efficient estimates of the parameters of interest and their asymptotic variance-covariance (Arellano and Bond 1991; Arellano and Bover 1995). However, given the limited size of our sample, in order to reduce the risk of overfitting bias, in the regression in differences we use only the first acceptable lag as an instrument. These are given by the following formulas:

$$
\hat{\theta}=\left(\bar{X}^{\prime} Z \hat{\Omega}^{-1} Z^{\prime} \bar{X}\right)^{-1} \bar{X}^{\prime} Z \hat{\Omega}^{-1} Z^{\prime} \bar{y}
$$

\footnotetext{
${ }^{5}$ Given that lagged levels are used as instruments in the differences specification, only the most recent difference is used as an instrument in the levels specification. Using other lagged differences would result in redundant moment conditions (see Arellano and Bover, 1995).
} 


$$
A \operatorname{VAR}(\hat{\theta})=\left(\bar{X}^{\prime} Z \hat{\Omega}^{-1} Z^{\prime} \bar{X}\right)^{-1}
$$

where $\theta$ is the vector of parameters of interest $(\alpha, \beta) ; \overline{\mathbf{y}}$ is the dependent variable stacked first in differences and then in levels; $\overline{\mathbf{x}}$ is the explanatory-variable matrix including the lagged dependent variable $\left(y_{t-1}, \mathbf{X}\right)$ stacked first in differences and then in levels; $\mathbf{Z}$ is the matrix of instruments derived from the moment conditions; and $\hat{\Omega}$ is a consistent estimate of the variance-covariance matrix of the moment conditions. ${ }^{6}$

The consistency of the GMM estimators depends on whether lagged values of the explanatory variables are valid instruments in the growth regression. We address this issue by considering two specification tests suggested by Arellano and Bond (1991) and Arellano and Bover (1995). The first is a Sargan test of overidentifying restrictions, which tests the overall validity of the instruments by analyzing the sample analog of the moment conditions used in the estimation process. Failure to reject the null hypothesis gives support to the model. ${ }^{7}$

The second test examines the null hypothesis that the error term, $\varepsilon_{i, t}$, is not serially correlated. As in the case of the Sargan test, the model specification is supported when the null hypothesis is not rejected. In the system specification, we test whether the differenced error term (that is, the residual of the regression in differences) is second-order serially correlated. First-order serial correlation of the differenced error term is expected even if the original error term (in levels) is uncorrelated, unless the latter follows a random walk. Second-order serial correlation of the differenced residual indicates that the original error term is serially correlated and follows a moving average process of at least order one. This would reject the appropriateness of the proposed instruments (and would call for higherorder lags to be used as instruments).

\footnotetext{
${ }^{6}$ Arellano and Bond (1991) suggest the following two-step procedure to obtain consistent and efficient GMM estimates. First, assume that the residuals, $\varepsilon_{i, t}$, are independent and homoskedastic both across countries and over time; this assumption corresponds to a specific weighting matrix that is used to produce first-step coefficient estimates. Second, construct a consistent estimate of the variance-covariance matrix of the moment conditions with the residuals obtained in the first step, and then use this matrix to re-estimate the parameters of interest (that is, second-step estimates). Asymptotically, the second-step estimates are superior to the first-step ones insofar as efficiency is concerned.

${ }^{7}$ There are cases where the Sargan test statistic cannot be computed given the near singularity of variancecovariance of the moment conditions. This arises when the cross-sectional dimension is small relative to the number of instruments. In those cases, of which we have a couple in our econometric results, we have to rely only on the residual autocorrelation test.
} 


\subsection{Results}

Regression results are presented in Tables 1 and 2. Table 1 shows the results of the basic regression with no interaction terms (column 1) and the results of the regressions where openness is interacted with time-varying variables (columns 2-5). These variables represent areas where economic reform has been most active; they are human capital investment, financial depth, macroeconomic price instability, and public infrastructure, respectively. Table 2 shows the regression results where openness is interacted with timeinvariant variables. They represent institutional and regulatory areas where reform --often called of second generation-- has been most sluggish. They are indices of governance, labor market flexibility, firm-entry flexibility, and firm-exit flexibility. We treat them as constant per country because their underlying institutional characteristics vary little over time and, partly reflecting this, there is quite limited data on their time dimension. ${ }^{8}$

The basic regression (Table 1, Col. 1) shows results consistent with the previous empirical literature. Initial GDP per capita carries a significantly negative coefficient, commonly interpreted as evidence of conditional convergence. The proxies of human capital investment, financial depth, and public infrastructure have positive and significant coefficients, denoting their beneficial impact on economic growth. Inflation, on the other hand, carries a negative coefficient, indicating the negative consequence of macroeconomic price instability. Trade openness is also a significant explanatory variable; as in other studies that rely on the cross-country variation of within-country changes, trade openness is found to have a positive impact on economic growth. Since in this basic specification only linear effects are allowed, the estimated openness impact on growth is an average effect; below we attempt to uncover what is behind this average. The period shifts indicate that international conditions for growth have deteriorated over time, resulting in considerably poorer conditions in the 1980s and 1990s than in the previous decades. Finally, both the Sargan and serial-correlation tests indicate that the null hypothesis of correct specification cannot be rejected, lending support to our estimation results. This is

\footnotetext{
${ }^{8}$ The ICRG governance index is available since the mid 1980 s and shows some time variation. Given that we are forced to assume that its value was the same in the 1960s and 1970s as in the mid 1980s, we take the conservative assumption that its growth effect cannot be estimated separately from that of the unobserved fixed effect, as is the case with the other institutional variables that are completely constant over time.
} 
the case for the exercises presented below, and we mention it only here in order to avoid redundancy.

Table 1 also shows the regressions results that consider interaction effects between openness and time-varying variables (Cols. 2-5). An interesting pattern of reform complementarity emerges: the coefficient on the interaction between the trade volume ratio and, in turn, the secondary enrollment rate, the private domestic credit ratio, and the number of phone lines per capita is positive and significant. This indicates that the growth effect of an increase in openness depends positively on the progress made in each of these areas. That is, more openness results in a larger increase in economic growth when the investment in human capital is stronger, financial markets are deeper, and public infrastructure is more readily available. The shared explanation for these results is related to the competitiveness of domestic firms in international markets: when domestic firms find a better educated labor force and less costly credit and communications, they are able to compete with foreign firms and expand their markets effectively. The interaction between trade volumes and inflation is not significant, possibly reflecting the fact that for most inflation values, relative price distortions are not severe.

Table 2 shows the growth regression results when openness is interacted with the proxies of institutional and regulatory reform. Interestingly, as in the results related to time-varying variables, we observe a pattern of complementarity between openness and other reforms: the estimated coefficients on the interaction between the trade volume ratio and, in turn, the proxies for governance, labor-market flexibility, and firm-entry flexibility are positive and statistically significant. The beneficial impact of an increase in trade openness on economic growth is larger when society has a more efficient, accountable, and honest government and where the rule of law is more respected. Likewise, the positive growth effect of trade opening is stronger when flexible labor markets make it easier for domestic firms to transform and adjust to changing environments, particularly those in highly competitive foreign markets. Our results also point out the importance of unrestricted firm renewal in order for trade opening to have a positive growth impact, particularly regarding the firm-entry margin. The interaction term between openness and firm-exit flexibility is, however, not significant; whether this reflects data-quality problems or a more substantial difference with the opposite margin of firm dynamics is unclear. 
The preceding discussion focuses on the interaction terms; however, in order to ascertain whether the total impact of a change in openness leads to higher or lower growth, we need to consider the coefficients on both the interaction term and the openness variable itself. Since the total impact depends on the values of the variables with which openness is interacted, it is not really informative to provide a single summary measure of the effect. Instead, it may be best to show how the growth effect of a change in openness varies for different levels of the other reform variables. We do so in Figure 2. Specifically, this figure presents the total effect on economic growth of a one-standard-deviation change in the openness measure for each value that a given complementary reform can take in the sample. Since only linear interaction effects are considered, the growth effect of openness can be represented as a linear function of each complementary reform. In addition to total growth effects (based on the coefficient point estimates), the figure shows the corresponding $90 \%$ confidence bands (constructed with the estimated coefficient standard errors). ${ }^{9}$ Figure 2 has six panels, each corresponding to a reform variable whose interaction with openness is statistically significant. For time-varying variables, the range of values corresponding to the latest period (1996-2000) is found towards the higher values of the full (all-periods) range; since for current policy analysis the latest values are the most relevant, we highlight their range in the corresponding panel.

For all reform variables except the governance index, the total growth impact of openness changes from negative to positive as progress occurs. Therefore, in principle, an increase in openness could bring a reduction in economic growth if a given complementary area is not sufficiently advanced. In practice, given the current state of reform progress around the world, this concern is presently relevant for half the complementary areas under consideration. For educational enrollment, financial development, and governance, our

\footnotetext{
${ }^{9}$ From our regression model, the growth effect of openness is given by, $\triangle$ Growth $=\left(\beta_{\text {OPEN }}+\beta_{\text {INT }}\right.$ REF $) \Delta$ Openness

where $\beta_{O P E N}$ and $\beta_{I N T}$ are, respectively, the estimated regression coefficients on openness and on the interaction between openness and a given complementary reform variable $(R E F)$. Note that $\triangle$ Openness is an arbitrary constant (set to equal one sample standard deviation of the openness measure) and $R E F$ follows a fixed set of values (and can thus be treated as a constant at any given point along its sample range). Then, the confidence intervals can be constructed from the following expression for the variance of the growth effect,

$\operatorname{Var}[\Delta$ Growth $]=\left\{\operatorname{Var}\left(\beta_{\text {OPEN }}\right)+\operatorname{Var}\left(\beta_{I N T}\right) R E F^{2}+\operatorname{Cov}\left(\beta_{\text {OPEN }}, \beta_{I N T}\right) R E F\right\}\{\Delta \text { Openness }\}^{2}$

where the variances and covariances of the estimated coefficients are obtained from our panel estimation method.
} 
results indicate that they would not cause growth to decline with increased openness given that their current values in most countries exceed the corresponding threshold. However, regarding infrastructure, labor market flexibility, and firm entry flexibility, there are many countries that currently stand to lose from opening their markets. Focusing only on the reform indicators used in the paper, we can derive the implication that the most urgent reforms in order to make trade good for growth are related to infrastructure, labor markets, and firm renewal. This is not to say, however, that countries will not benefit more from trade openness if they improve their educational attainment, financial depth, and overall governance.

So far we have considered only linear interactions between openness and other variables one at a time. A richer specification would allow for both non-linear interactions and interactions with multiple variables at the same time. The problem with richer specifications, however, is that the possibilities are almost endless. Our limited sample, demanding econometric methodology, and the multicollinearity among growth determinants prevent us from exploring a full set of interactions. However, some progress can be made by expanding our specification to include the interaction between openness and initial income to each of the regression specifications studied above and examining the sign and significance of the coefficient on this interaction. This exercise links our results to the literature discussed in the introduction, which finds that the growth effect of openness depends on the countries' level of income. That literature argues that income represents overall development and is thus strongly related to the social and economic conditions that improve openness' beneficial impact. We find confirmation for this claim in the fact that, in our sample, initial income has a $90 \%$ correlation with the first principal component of our six complementary reforms, meaning that income represents well what is common among these development variables. Therefore, we can analyze whether it is the full package of reforms what makes openness better for growth by examining if, in the expanded specification, the coefficient on the openness-initial income interaction is positive and significant in most cases. It is also of interest to check whether, after the openness-initial income interaction is included, the interaction of openness with certain individual reforms remain significant. If so, the effect of those reforms on the openness- 
growth relation is independent to that of the other reforms as a whole. In that sense, they would be "more complementary" to openness than the rest.

Table 3 presents the main results of the expanded regression specification. In the benchmark (column 1), only the openness-initial income interaction is considered; it carries a significantly positive coefficient, as expected and predicted by previous literature. In the remaining cases, the interactions between openness and, respectively, educational investment, financial depth, public infrastructure, governance, labor-market flexibility, and firm-entry flexibility are added one at a time.

In five out of the six cases the openness-income interaction remains significantly positive, denoting that in the majority of cases the combination of all complementary reform variables (represented by income) is a key determinant on the growth impact of openness. ${ }^{10}$ Overall, therefore, our results underscore the benefits of a comprehensive path to reform.

The inclusion of the openness-initial income interaction term makes the coefficients of the interaction between openness and human capital investment, financial depth, public infrastructure, and governance lose their sign or become statistically insignificant. As we have discussed, we interpret this result as suggesting that these complementary areas must be addressed as a whole if they are to affect the opennessgrowth link. In contrast, the coefficients on the interaction of openness and, respectively, labor market flexibility and firm entry flexibility remain significant at the five percent level. Reforms of the labor market and firm entry conditions appear, therefore, to have a significant effect on the impact of openness on growth, independently of other reforms.

\section{ConCluding Remarks}

As discussed in the introduction, previous empirical evidence on the impact of trade openness on economic growth has failed to reveal undisputed beneficial growth effects from trade liberalization. Both the theory and the evidence reviewed in this paper, however, indicate that such a failure should not have come as a surprise. It is not too hard to find theoretical situations in which the removal of barriers to trade needs to be

\footnotetext{
${ }^{10}$ The exception occurs when the interaction between openness and firm-entry flexibility is also present. In that case, the coefficient of the openness-income interaction term becomes insignificant, although its sign remains positive.
} 
accompanied by complementary reforms in non-trade areas if it is to improve productive efficiency and growth. And our empirical work finds that such situations may not be uncommon in practice.

One policy implication of our analysis is that the advisability of trade liberalization may depend on the existence and degree of distortions in non-trade institutions, as well as on the feasibility of removing those distortions. This underscores the need to reject a "one size fits all" approach to trade opening in favor of packages that are tailored to the specific circumstances of each country.

This being said, we believe that our findings provide fresh support to the view that trade liberalization tends to enhance growth. Our empirical work does confirm that trade opening results in faster growth on average, that is, when the interaction effects are omitted from our regressions. And if the interaction terms are included, trade liberalization turns out to still raise growth, except for countries in which complementary areas are strongly distorted.

In addition, and conversely, our findings indicate that "second generation" reforms have not only direct benefits but also indirect ones, in that they allow a country to take fuller advantage of trade opening. This is a significant argument in the ongoing debate about the gains from more comprehensive reform in developing countries. 


\section{References}

Acemoglu, D. and F. Zilibotti (2001). "Productivity Differences." Quarterly Journal of Economics 116(2): 563-606.

Alfaro, L., A. Chanda, S. Kalemli-Ozcan, and S. Sayek (2003). "FDI Spillovers, Financial Markets and Economic Development.” IMF Working Papers 03/186.

Alonso-Borrego, C. and M. Arellano (1999). "Symmetrically Normalized InstrumentalVariable Estimation Using Panel Data." Journal of Business and Economic Statistics 17(1): 36-49.

Arellano, M., and S. Bond (1991). "Some Tests of Specification for Panel Data: Montecarlo Evidence and an Application to Employment Equations." Review of Economic Studies 58(2): 277-297.

Arellano, M., and O. Bover (1995). "Another Look at the Instrumental-Variable Estimation of Error-Components Models." Journal of Econometrics 68(1): 29-52.

Banerjee, A. and A. Newman (2004). "Notes for Credit, Growth, and Trade Policy." Mimeo. MIT.

Beck, T., A. Demirguc-Kunt, and R. Levine (2000). "A New Database on Financial Development and Structure." The World Bank Economic Review 14(3): 597-605.

Blundell, R. and S. Bond (1997). "Initial Conditions and Moment Restrictions in Dynamic Panel Data Models". University College London Discussion Papers in Economics: 97/07, July.

Bolaky, B. and C. Freund (2004). "Trade, Regulations, and Growth.” World Bank Policy Research Paper Series 3255.

Borensztein, E., J. De Gregorio, J-W. Lee (1995). "How Does Foreign Direct Investment Affect Economic Growth?" Journal of International Economics 45, 1: 115-35.

Botero, J., S. Djankov, R. La Porta, F. Lopez-de-Silanes, and A. Shleifer (2004). "The Regulation of Labor." Quarterly Journal of Economics 119: 1339-1382.

Brecher, R. (1974). "Optimal Commercial Policy for a Minimum-wage Economy." Journal of International Economics 4: 139-149.

Calderon, C., N. Loayza, and K. Schmidt-Hebbel (2004). "External Conditions and Growth Performance." Central Bank of Chile Working Paper N. 292.

Canning, D. (1998). "A Database of World Stocks of Infrastructure." The World Bank Economic Review 12: 529-547. 
Djankov, S., R. La Porta, F. Lopez-de-Silanes and A. Shleifer (2002). "The Regulation of Entry." Quarterly Journal of Economics 117: 1-37.

Djankov, S., O. Hart, T. Nenova, and A. Shleifer (2003). "Efficiency in Bankruptcy." Working Paper, Department of Economics, Harvard University.

Dollar, D. (1992). "Outward-oriented Developing Economies Really D Grow More Rapidly: Evidence from 95 LDCs, 1976-85." Economic Development and Cultural Change, 523-44.

Dollar, D. and A. Kraay (2004). "Trade, Growth, and Poverty." Economic Journal 114(493): F22-49.

Easterly, W. and M. Sewadeh (2002). "Global Development Network Growth Database." Washington: World Bank.

Edwards, S. (1998). “Openness, Productivity, and Growth: What Do We Really Know?" Economic Journal 108 (447): 383-98.

Eicher, T. (1993). "Trade and Converging Growth Rates in a Model with Endogenous Human Capital and Technological Change: Dynamic Gains from Trade Reconsidered." Unpublished paper. Columbia University.

Griliches, Z. and J. Hausman (1986). "Errors in Variables in Panel Data." Journal of Econometrics 31(1): 93-118.

Grossman, G. and E. Helpman (1991). Innovation and Growth in the Global Economy. Cambridge, Mass.: MIT Press.

Harrison, A. (1996). "Openness and Growth: A Time-Series, Cross-Country Analysis for Developing Countries." Journal of Development Economics 48(2): 419-47.

Holtz-Eakin, D. W. Newey, and H. S. Rosen (1998). "Estimating Vector Autoregressions with Panel Data." Econometrica 56: 1371-1395

Lee, J. (1993). "International Trade, Distortions, and Long-Run Economic Growth." International Monetary Fund Staff Papers 40(2): 299-328.

Levine, R., N. Loayza, and T. Beck (2000). "Financial Intermediation and Growth: Causality and Causes." Journal of Monetary Economics 46, No.1: 31-77.

Lipsey, R. and K. Lancaster (1956). "General Theory of Second Best." Review of Economic Studies 24(1): 11-32. 
Loayza, N., P. Fajnzylber, and C. Calderon (2005). "Economic Growth in Latin America: Stylized Facts, Explanations, Forecasts." in World Bank Latin American and Caribbean Studies, Washington, D.C.: The World Bank.

Matsuyama, K. (1992). "Agricultural Productivity, Comparative Advantage, and Economic Growth." Journal of Economic Theory 58(2): 317-334.

O’Driscoll, G., E. Feulner, and M. A. O'Grady (2003). 2003 Index of Economic Freedom. The Heritage Foundation and the Wall Street Journal.

Political Risk Services (2003). International Country Risk Guide. East Syracuse, N.Y.: Political Risk Services.

Rodrik, D. and F. Rodríguez (2001). "Trade Policy and Economic Growth: A Skeptics Guide to the Cross-National Evidence." in B. Bernanke and K. Rogoff (editors), NBER Macroeconomics Annual 2000, Vol. 15, MIT Press: 261-325.

Sachs, J. D. and A. Warner (1995). "Economic Reform and the Process of Global Integration." Brooking Papers on Economic Activity, 1-118.

Sachs, J. and A. Warner (1999). "The Big Push, Natural Resource Booms and Growth." Journal of Development Economics 59(1): 43-76.

Summers, R. and A. Heston (1991). "The Penn World Table (Mark 5): An Expanded Set of International Comparisons, 1950-1988." Quarterly Journal of Economics 106(2): 32768.

Wacziarg, R. and K. H. Welch (2003). "Trade Liberalization and Growth: New Evidence." NBER Working Paper 10152, Cambridge, MA.

World Bank (2003). Doing Business. Washington, D.C.: The World Bank.

World Bank (2003). World Development Indicators. Washington, D.C.: The World Bank.

Young, A. (1991). "Learning by Doing and the Dynamic Effects of International Trade." Quarterly Journal of Economics 106(2): 369-405. 
Table 1

Economic Growth and the Interaction between Openness and Other Economic Reforms

Cross-country panel data consisting of non-overlapping 5-year averages spanning 1960-2000

Dependent variable: Growth rate of real GDP per capita

Estimation Method: GMM-IV System Estimator (Arellano and Bover, 1995; Blundell and Bond, 1998)

\begin{tabular}{|c|c|c|c|c|c|}
\hline & \multirow[b]{2}{*}{$\begin{array}{c}{[1]} \\
\text { Benchmark: No } \\
\text { Interactions }\end{array}$} & \multicolumn{4}{|c|}{ Interaction of Openness with: } \\
\hline & & $\begin{array}{c}{[2]} \\
\text { Human Capital } \\
\text { Investment } \\
\end{array}$ & $\begin{array}{c}\text { [3] } \\
\text { Financial Depth }\end{array}$ & $\begin{array}{c}\text { [4] } \\
\text { Inflation }\end{array}$ & $\begin{array}{c}{[5]} \\
\text { Public } \\
\text { Infrastructure } \\
\end{array}$ \\
\hline \multicolumn{6}{|l|}{ Control Variables: } \\
\hline $\begin{array}{l}\text { Initial GDP per capita } \\
\text { (in logs) }\end{array}$ & $\begin{array}{l}-3.1713 \text { ** } \\
0.18\end{array}$ & $\begin{array}{l}-3.2036 * * \\
0.21\end{array}$ & $\begin{array}{l}-3.2627 * * \\
0.17\end{array}$ & $\begin{array}{l}-3.2059 * * \\
0.18\end{array}$ & $\begin{array}{l}-3.3552 \text { ** } \\
0.23\end{array}$ \\
\hline $\begin{array}{l}\text { Human capital investment } \\
\text { (secondary enrollment, in logs) }\end{array}$ & $\begin{array}{l}1.1621 * * \\
0.15\end{array}$ & $\begin{array}{c}-0.8610 * * \\
0.42\end{array}$ & $\begin{array}{l}1.2105 \text { ** } \\
0.16\end{array}$ & $\begin{array}{l}1.1402 \text { ** } \\
0.16\end{array}$ & $\begin{array}{l}1.2594 * * \\
0.17\end{array}$ \\
\hline $\begin{array}{l}\text { Financial depth } \\
\text { (private domestic credit/GDP, in logs) }\end{array}$ & $\begin{array}{l}1.0272 \text { ** } \\
0.11\end{array}$ & $\begin{array}{l}0.9421 \text { ** } \\
0.09\end{array}$ & $\begin{array}{r}0.0262 \\
0.21\end{array}$ & $\begin{array}{l}1.0071 * * \\
0.11\end{array}$ & $\begin{array}{l}0.9234 \text { ** } \\
0.07\end{array}$ \\
\hline $\begin{array}{l}\text { Inflation } \\
\text { (deviation of inflation rate from }-3 \% \text {, in logs) }\end{array}$ & $\begin{array}{l}-0.4580 * * \\
0.08\end{array}$ & $\begin{array}{l}-0.4350 * * \\
0.07\end{array}$ & $\begin{array}{l}-0.4895 * * \\
0.07\end{array}$ & $\begin{array}{r}-0.3243 \\
0.21\end{array}$ & $\begin{array}{c}-0.4364 * * \\
0.07\end{array}$ \\
\hline $\begin{array}{l}\text { Public infrastructure } \\
\text { (main telephone lines per capita, in logs) }\end{array}$ & $\begin{array}{l}1.5764 \text { ** } \\
0.13\end{array}$ & $\begin{array}{l}1.5904 \text { ** } \\
0.16\end{array}$ & $\begin{array}{l}1.6053 \text { ** } \\
0.14\end{array}$ & $\begin{array}{l}1.6050 * * \\
0.14\end{array}$ & $\begin{array}{l}0.6423 \\
0.19\end{array}$ \\
\hline \multicolumn{6}{|l|}{ Openness: } \\
\hline $\begin{array}{l}\text { Trade Openness (TO) } \\
\text { (structure-adjusted trade volume/GDP, in logs) }\end{array}$ & $\begin{array}{l}1.1959 \text { ** } \\
0.16\end{array}$ & $\begin{array}{c}-2.0421 * * \\
0.59\end{array}$ & $\begin{array}{r}-0.2553 \\
0.28\end{array}$ & $\begin{array}{l}1.3497 \text { ** } \\
0.28\end{array}$ & $\begin{array}{c}3.2821 \\
0.48\end{array}$ \\
\hline \multicolumn{6}{|l|}{ Interactions: } \\
\hline TO $*$ Human capital investment & & $\begin{array}{l}1.0031 \text { ** } \\
0.18\end{array}$ & & & \\
\hline TO * Financial depth & & & $\begin{array}{l}0.4629 * * \\
0.08\end{array}$ & & \\
\hline TO $*$ Inflation & & & & $\begin{array}{r}-0.0725 \\
0.10\end{array}$ & \\
\hline TO * Public infrastructure & & & & & $\begin{array}{l}0.4970 \text { ** } \\
0.09\end{array}$ \\
\hline \multicolumn{6}{|l|}{ Period Shifts: } \\
\hline Intercept (base period: 1966-70) & $26.6266 * *$ & $33.8398 * *$ & $30.5385 * *$ & $26.8523 * *$ & $24.3839 * *$ \\
\hline $\begin{array}{l}\text { - 71-76 Period shift } \\
\text { - 76-80 Period shift } \\
\text { - 81-85 Period shift } \\
\text { - 86-90 Period shift } \\
\text { - 91-95 Period shift } \\
\text { - 96-00 Period shift }\end{array}$ & $\begin{array}{l}-0.2987 * \\
-1.1300 * * \\
-3.3327 * * \\
-2.9064 * * \\
-3.6060 * * \\
-4.3282 * *\end{array}$ & $\begin{array}{l}-0.2371 \\
-1.1488 * * \\
-3.3847 * * \\
-3.0726 * * \\
-3.8088 * * \\
-4.6922 * *\end{array}$ & $\begin{array}{l}-0.2168 \\
-1.0385 * * \\
-3.2966 * * \\
-2.9450 * * \\
-3.6621 * * \\
-4.4665 * *\end{array}$ & $\begin{array}{l}-0.2698 \\
-1.1052 * * \\
-3.3011 * * \\
-2.8904 * * \\
-3.6020 * * \\
-4.3250 * *\end{array}$ & $\begin{array}{l}-0.2973 * * \\
-1.1850 * * \\
-3.4343 * * \\
-3.1684 * * \\
-3.9486 * * \\
-4.8331 * *\end{array}$ \\
\hline Countries / Observations & $82 / 544$ & $82 / 544$ & $82 / 544$ & $82 / 544$ & $82 / 544$ \\
\hline $\begin{array}{l}\text { Specification Tests (p-values) } \\
\text { - Sargan Test } \\
\text { - 2nd. Order Correlation }\end{array}$ & $\begin{array}{l}0.42 \\
0.15\end{array}$ & $\begin{array}{l}0.42 \\
0.14\end{array}$ & $\begin{array}{l}0.37 \\
0.15\end{array}$ & $\begin{array}{l}0.39 \\
0.14\end{array}$ & $\begin{array}{l}0.47 \\
0.14\end{array}$ \\
\hline
\end{tabular}

Numbers below coefficients are the corresponding robust standard errors. * (**) denotes statistical significance at the 10 (5) percent level.

Source: Authors' calculations 
Table 2

Economic Growth and the Interaction between Openness and Institutional/Regulatory Reforms ${ }^{1}$

Cross-country panel data consisting of non-overlapping 5-year averages spanning 1960-2000

Dependent variable: Growth rate of real GDP per capita

Estimation Method: GMM-IV system estimator for dynamic models with unobserved specific effects and endogenous regressors

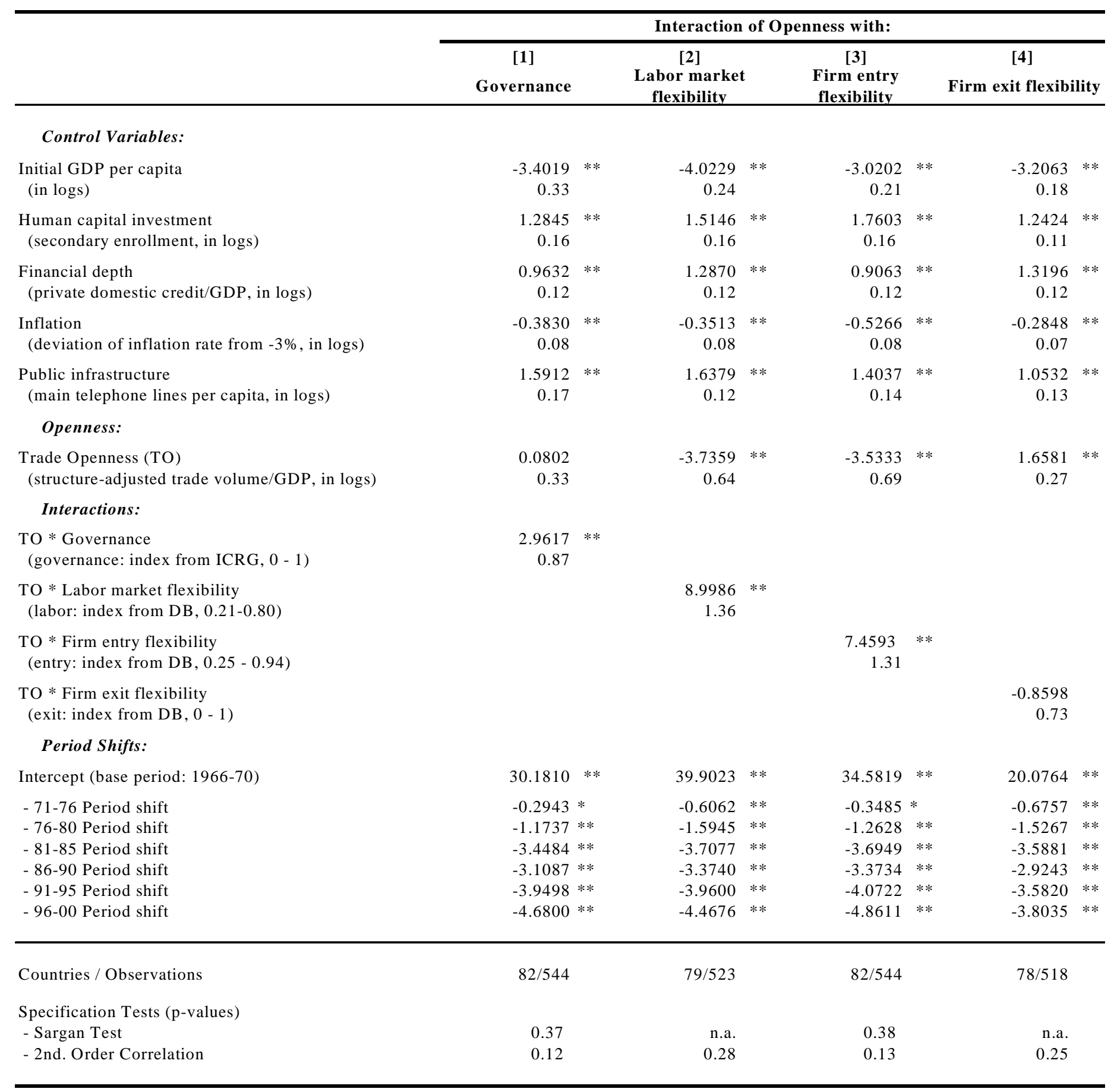

Numbers below coefficients are the corresponding robust standard errors. * (**) denotes statistical significance at the 10 (5) percent level.

${ }^{1}$ Our measures of institutional and regulatory reform do not vary, or vary little, over time. Their direct impact on growth cannot be separated from that of the country-specific effect; however, we include them as an additional control.

Source: Authors' calculations 
Table 3

Economic Growth and the Interaction between Openness, Reforms, and Income ${ }^{1}$

Cross-country panel data consisting of non-overlapping 5-year averages spanning 1960-2000

Dependent variable: Growth rate of real GDP per capita

Estimation Method: GMM-IV System Estimator (Arellano and Bover, 1995; Blundell and Bond, 1998)

\begin{tabular}{|c|c|c|c|c|c|}
\hline & \multirow{2}{*}{\multicolumn{2}{|c|}{$\begin{array}{c}\text { [1] } \\
\text { Benchmark }\end{array}$}} & \multicolumn{3}{|c|}{ Interaction of Openness with: } \\
\hline & & & $\begin{array}{c}{[2]} \\
\text { Human Capital } \\
\text { Investment }\end{array}$ & $\begin{array}{c}\text { [3] } \\
\text { Financial Depth }\end{array}$ & $\begin{array}{c}{[4]} \\
\text { Public } \\
\text { Infrastructure }\end{array}$ \\
\hline TO $*$ Initial GDP per Capita & $\begin{array}{c}1.0067 \\
0.21\end{array}$ & $* *$ & $\begin{array}{rl}0.9237 & * * \\
0.27 & \end{array}$ & $\begin{array}{c}1.2174 * * \\
0.30\end{array}$ & $\begin{array}{r}1.2644 \text { ** } \\
0.41\end{array}$ \\
\hline TO $*$ Human capital investment & & & $\begin{array}{r}0.1200 \\
0.30\end{array}$ & & \\
\hline TO $*$ Financial depth & & & & $\begin{array}{c}-0.2711 * \\
0.15\end{array}$ & \\
\hline TO $*$ Public infrastructure & & & & & $\begin{array}{c}-0.1550 \\
0.17\end{array}$ \\
\hline Countries / Observations & $82 / 544$ & & $82 / 544$ & $82 / 544$ & $82 / 544$ \\
\hline
\end{tabular}

\begin{tabular}{|c|c|c|c|c|}
\hline & \multicolumn{4}{|c|}{ Interaction of Openness with: } \\
\hline & $\begin{array}{c}{[5]} \\
\text { Governance }\end{array}$ & & $\begin{array}{c}{[6]} \\
\begin{array}{c}\text { Labor market } \\
\text { flexibility }\end{array} \\
\end{array}$ & $\begin{array}{c}\text { [7] } \\
\text { Firm entry } \\
\text { flexibility }\end{array}$ \\
\hline TO * Initial GDP per Capita & $\begin{array}{r}0.9340 \\
0.36\end{array}$ & $* *$ & $\begin{array}{l}0.3532 * * \\
0.16\end{array}$ & $\begin{array}{c}0.2452 \\
0.35\end{array}$ \\
\hline $\begin{array}{l}\mathrm{TO} * \text { Governance } \\
\text { (governance: index from ICRG, } 0 \text { - 1) }\end{array}$ & $\begin{array}{c}-0.7291 \\
1.36\end{array}$ & & & \\
\hline $\begin{array}{l}\mathrm{TO} * \text { Labor market flexibility } \\
\text { (labor: index from DB, 0.21-0.80) }\end{array}$ & & & $\begin{array}{l}9.5158 * * \\
1.39\end{array}$ & \\
\hline $\begin{array}{l}\text { TO * Firm entry flexibility } \\
\text { (entry: index from DB, } 0.25-0.94)\end{array}$ & & & & $\begin{array}{l}6.3057 * * \\
2.04\end{array}$ \\
\hline Countries / Observations & $82 / 544$ & & $79 / 523$ & $82 / 544$ \\
\hline
\end{tabular}

Numbers below coefficients are the corresponding robust standard errors. * (**) denotes statistical significance at the 10 (5) percent level.

${ }^{1}$ Each column in the table is part of a larger regression which includes the same control variables as tables 1 and 2 but that we do not present here for the sake of succinctness.

Source: Authors' calculations 

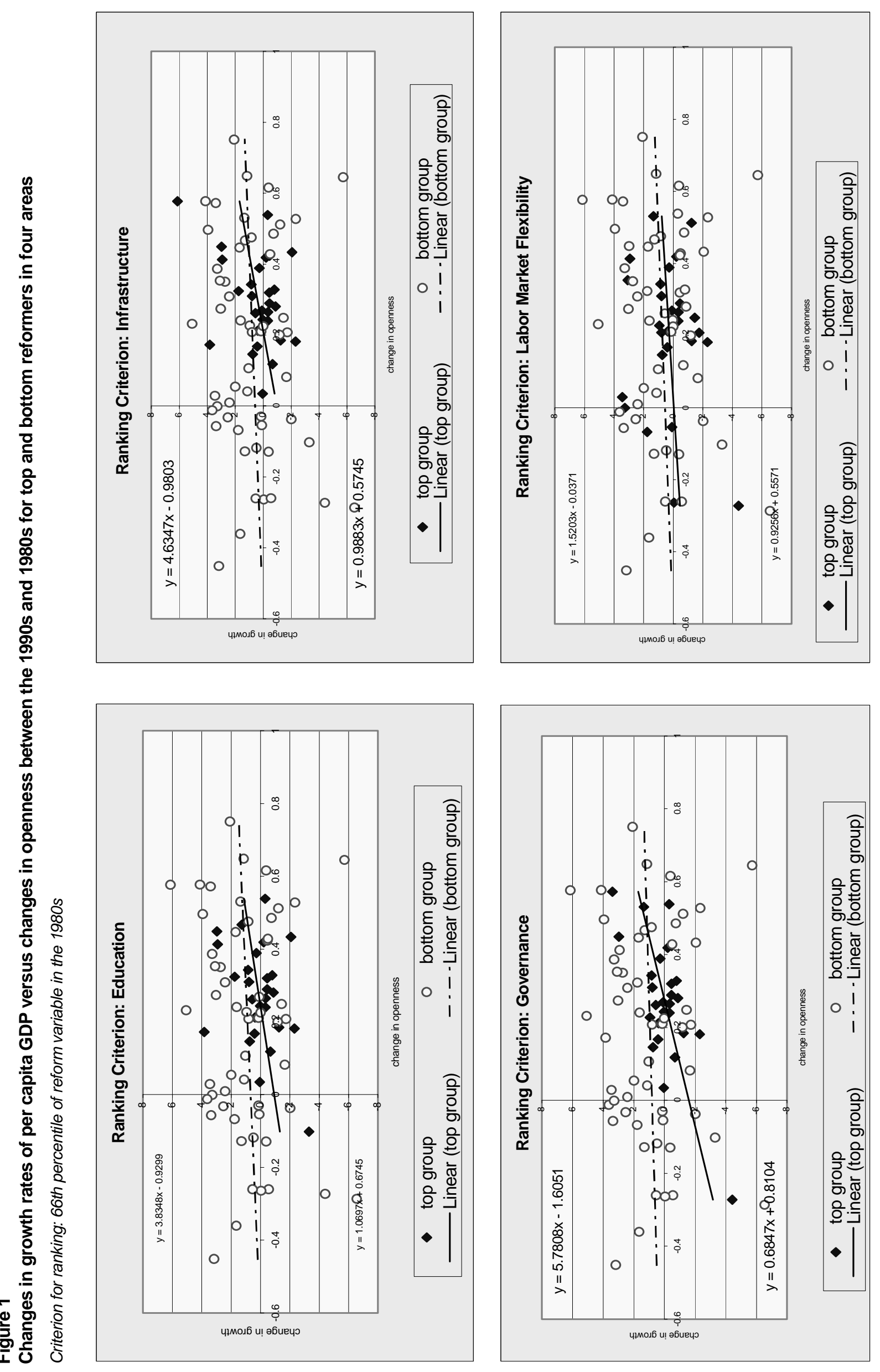

m

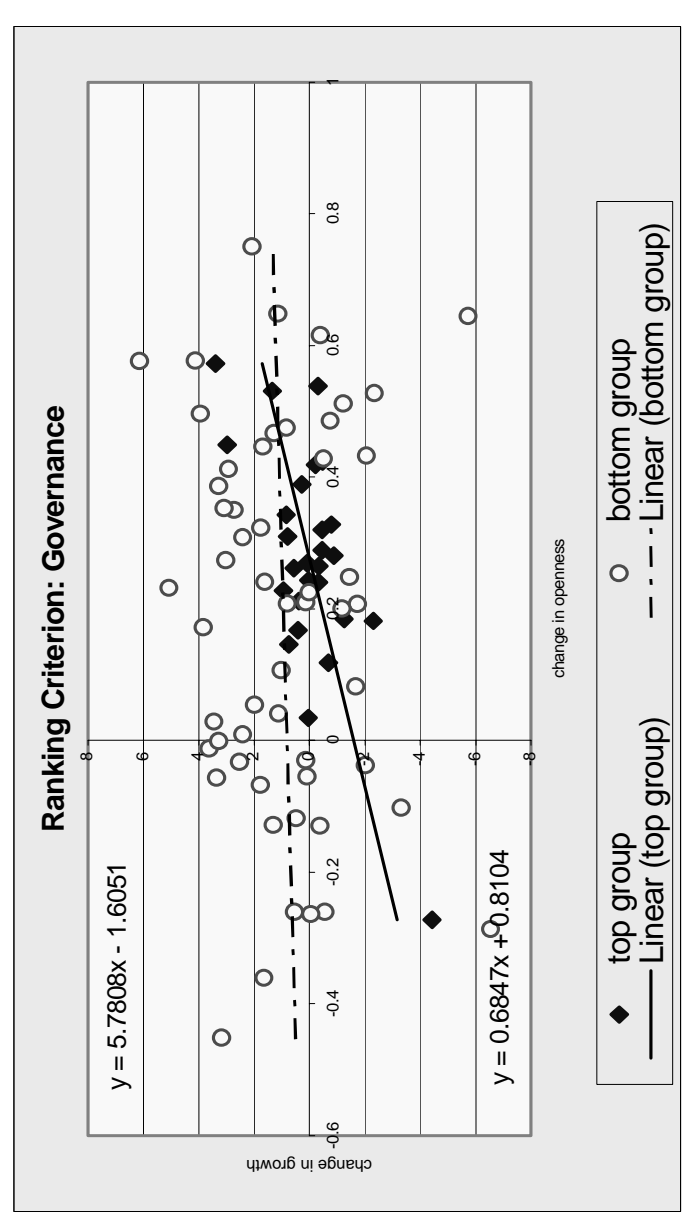


Figure 2

Growth Effect of Trade Openness as a Function of Complementary Reforms ${ }^{\star}$
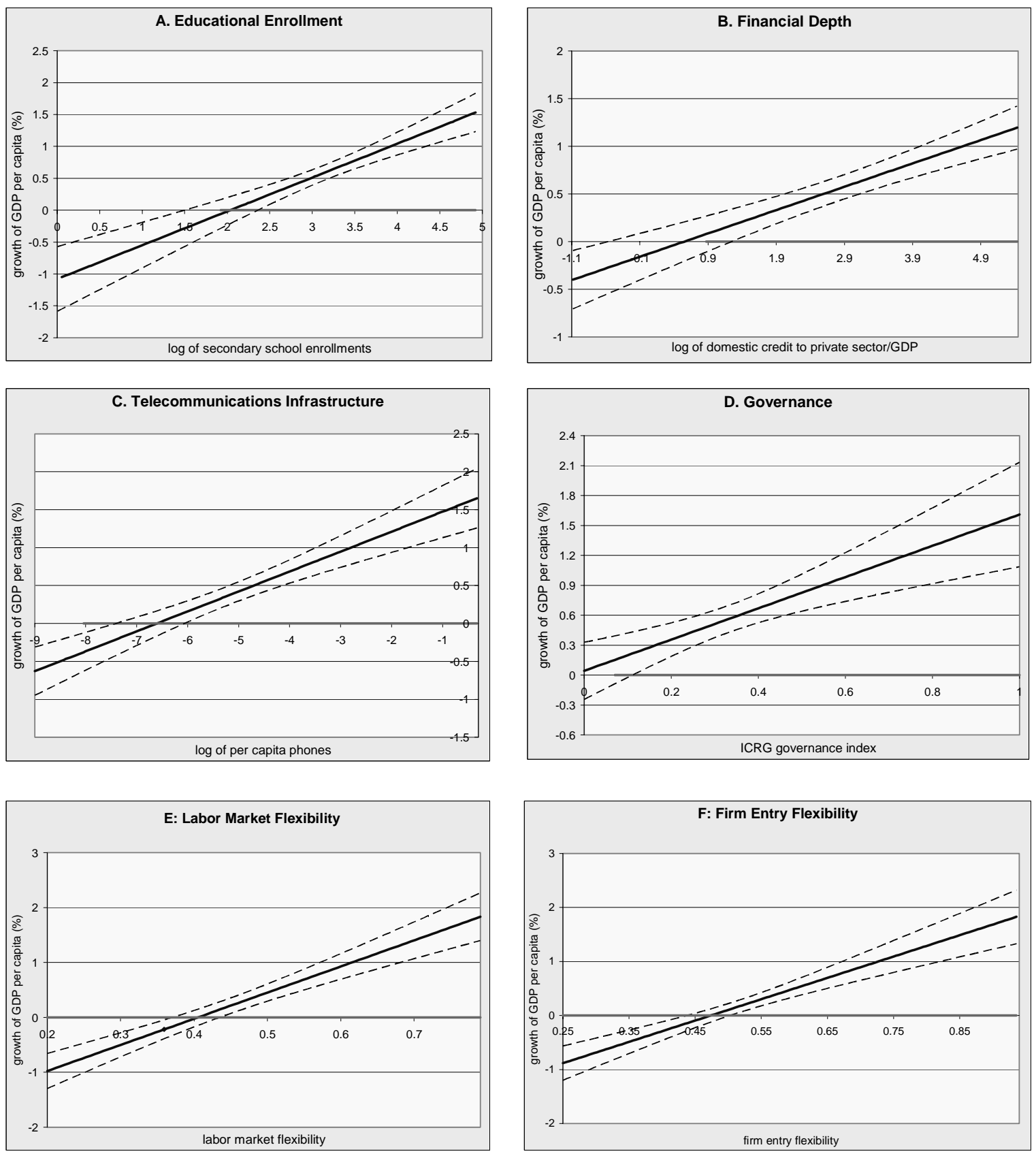

Notes:

1. The solid lines show the effect of a one standard deviation increase in the log of trade volume/GDP on the growth rate of GDP per capita.

2. The $x$ axis represents the range of the reform area in the full sample. The thicker line on the $x$ axis (when applicable) represents the range of the reform area in the period 1996-2000.

3. Dotted lines are $90 \%$ confidence bands. 


\section{Appendix 1: Sample of countries}

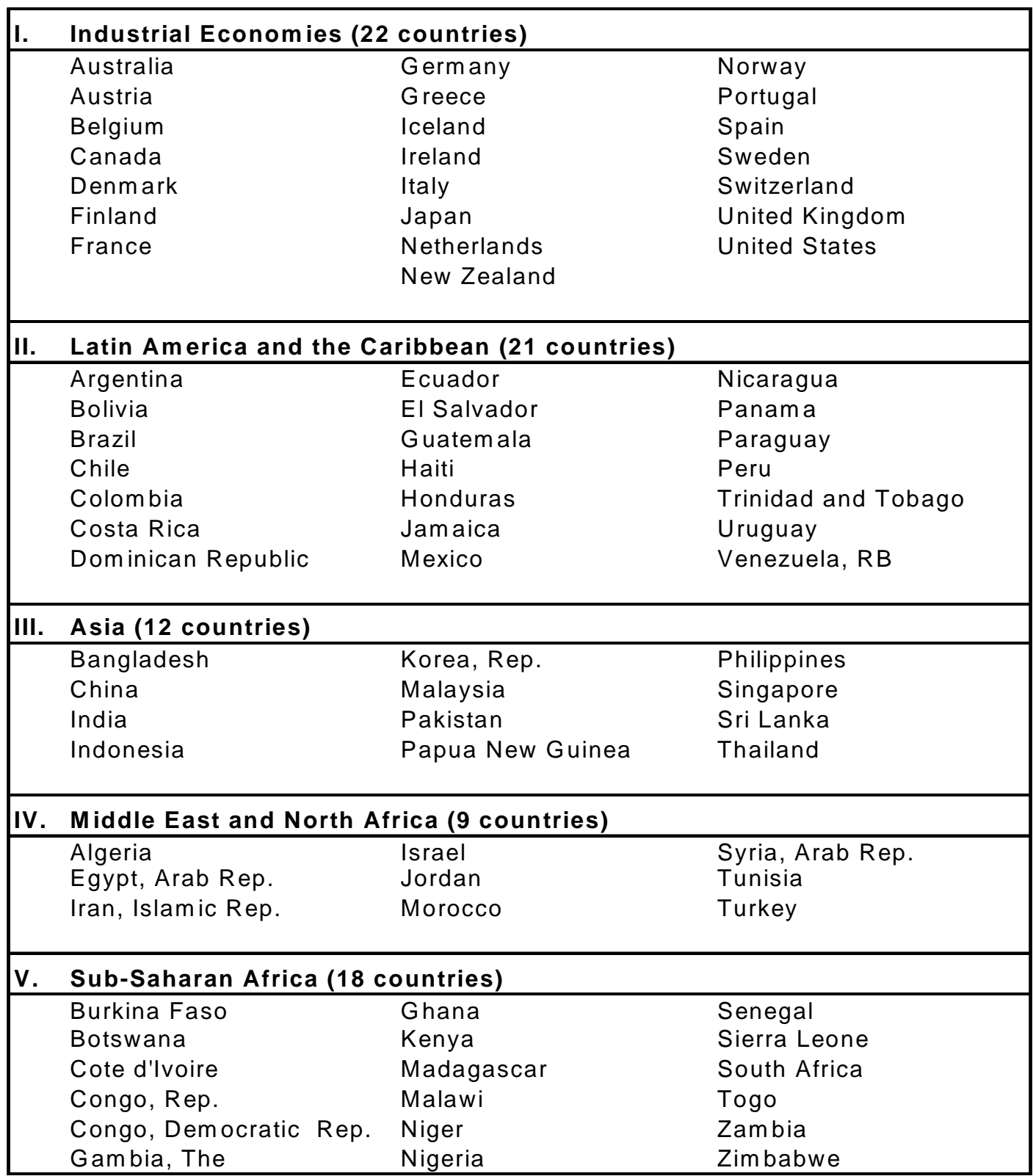


Appendix 2: Definitions and Sources of Variables Used in Regression Analysis

\begin{tabular}{ll}
\hline \multicolumn{1}{c}{ Variable } & \multicolumn{1}{c}{ Definition and Construction } \\
\hline GDP per capita growth & Log difference of real GDP per capita. \\
Initial GDP per capita & $\begin{array}{l}\text { Initial value of ratio of total GDP to total population. GDP is } \\
\text { in } 1985 \text { PPP-adjusted US\$. }\end{array}$ \\
Education & Ratio of total secondary enrollment, regardless of age, to the \\
& population of the age group that officially corresponds to that \\
& level of education. \\
& Telephone mainlines are telephone lines connecting a \\
Public Infrastructure & customer's equipment to the public switched telephone \\
& network. Data are presented in per capita terms. \\
First principal component of four indicators (prevalence of \\
law and order, quality of bureaucracy, absence of corruption, \\
and accountability of public officials). \\
Financial Depth
\end{tabular}

Trade Openness

Residual of a regression of the log of the ratio of exports and imports (in 1995 US\$) to GDP (in 1995 US\$), on the logs of area and population, and dummies for oil exporting and for landlocked countries.

Inflation rate Labor Market Flexibility

Source
Authors' construction using Summers and
Heston (1991) and The World Bank (2003).

Authors' construction using Summers and Heston (1991) and The World Bank (2003).

Easterly and Sewadeh (2002) and The World Bank (2003).

Canning (1998), International

Telecommunications Union.

International Country Risk Guide (ICRG), Political Risk Services, 2003.

www.icrgonline.com

Author's calculations using data from IFS, the publications of the Central Bank and PWD. The method of calculations is based on Beck, Demirguc-Kunt and Levine (2000).

Easterly and Sewadeh (2002) and The World Bank (2003).

Author's calculations with data from IFS. Doing Business, The World Bank Group See Botero, Djankov, La Porta, Lopez-de-Silanes and Shleifer, "The Regulation of Labor", Quarterly Journal of Economics, 119, 13391382, Nov. 2004.

http://rru.worldbank.org/doingbusiness/explor etopics/hiringfiringwork 


\section{Appendix 2 (continued): Definitions and Sources of Variables Used in Regression Analysis}

Firm Entry Flexibility
Composed of four indicators:

1) Entry procedures: The number of different procedures that a start-up has to comply with in order to obtain a legal status, i.e. to start operating as a legal entity. The data cover (1) procedures that are always required; (2) procedures that are generally required but that can be avoided in exceptional cases or for exceptional types of businesses.

2) Entry days: The average duration estimated necessary to complete a procedure. The fastest procedure (independent of cost) is chosen. It is assumed that the entrepreneur completes the procedure in the most efficient way, ignoring the time that the entrepreneur spends in information gathering.

3) Entry costs: Costs associated with starting-up a business, based on the texts of the Company Law, the Commercial Code, or specific regulations. If there are conflicting sources and the laws are not completely clear, the most authoritative source is used. If the sources have the same rank the source indicating the most costly procedure is used. In the absence of express legal fee schedules, a governmental officer's estimate is taken as an official source. If several sources have different estimates, the median reported value is used. In the absence of government officer's estimates, estimates of incorporation lawyers are used instead. If these differ, the median reported value is computed. In all cases, the cost estimate excludes bribes.

4) Entry regulations: i) Very Low: existing regulations straightforward and applied uniformly to all businesses; regulations not much of a burden for business; corruption nearly nonexistent. ii) Low: simple licensing procedures; existing regulations relatively straightforward and applied uniformly most of the time, but burdensome in some instances; corruption possible but rare iii) Moderate: complicated licensing procedure; regulations impose substantial burden on business; existing regulations may be applied haphazardly and in some instances are not even published by the government; corruption may be present and poses minor burden on businesses iv) High: government-set production quotas and some state planning; major barriers to opening a business; complicated licensing process; very high fees; bribes sometimes necessary; corruption present and burdensome; regulations impose a great burden on business v) Very High: Government impedes the creation of new businesses; corruption rampant; regulations applied randomly

Firm Exit Flexibility
Composed of three indicators: 1) A measure that documents the success in reaching the three goals of insolvency, as stated in Hart (1999). It is calculated as the simple average of the cost of insolvency (rescaled from 0 to 100, where higher scores indicate less cost), time of insolvency (rescaled from 0 to 100, where higher scores indicate less time), the observance of absolute priority of claims, and the efficient outcome achieved. A score 100 on the index means perfect efficiency. 2) The cost of the entire bankruptcy process, including court costs, insolvency practitioners' costs, the cost of independent assessors, lawyers, accountants, etc. In all cases, the cost estimate excludes bribes.
Doing Business, The World Bank Group See Djankov, La Porta, Lopez-de-Silanes and Shleifer, "The Regulation of Entry", Quarterly Journal of Economics, 117, 1-37, Feb. 2002. http://rru.worldbank.org/doingbusiness
The Index of Economic Freedom, Heritage Foundation Based on: Economist Intelligence Unit, Country Commerce and Country Report, 2001 and 2002, U.S. Department of State, Country Commercial Guide 24 and Country Reports on Economic Policy and Trade Practices. See O'Driscoll, G., E. Feulner, and M. A. O'Grady (2003).

Doing Business, The World Bank See Djankov, Simeon, Oliver Hart, Tatiana Nenova, and Andrei Shleifer, "Efficiency in Bankruptcy", working paper, Department of Economics, Harvard University, July 2003. 
Appendix 2 (continued): Definitions and Sources of Variables Used in Regression Analysis

The cost figures are averages of the estimates in a multiplechoice question, where the respondents choose among the following options: 0-2 percent, 3-5 percent, 6-10 percent, 11 25 percent, $26-50$ percent, and more than 50 percent of the insolvency estate value. 3) The degree to which the court drives insolvency proceedings. It is an average of three indicators: whether the court appoints and replaces the insolvency administrator with no restrictions imposed by law, whether the reports of the administrator are accessible only to the court and not creditors, and whether the court decides on the adoption of the rehabilitation plan. The index is scaled from 0 to 100 , where higher values indicate more court involvement in the insolvency process. 


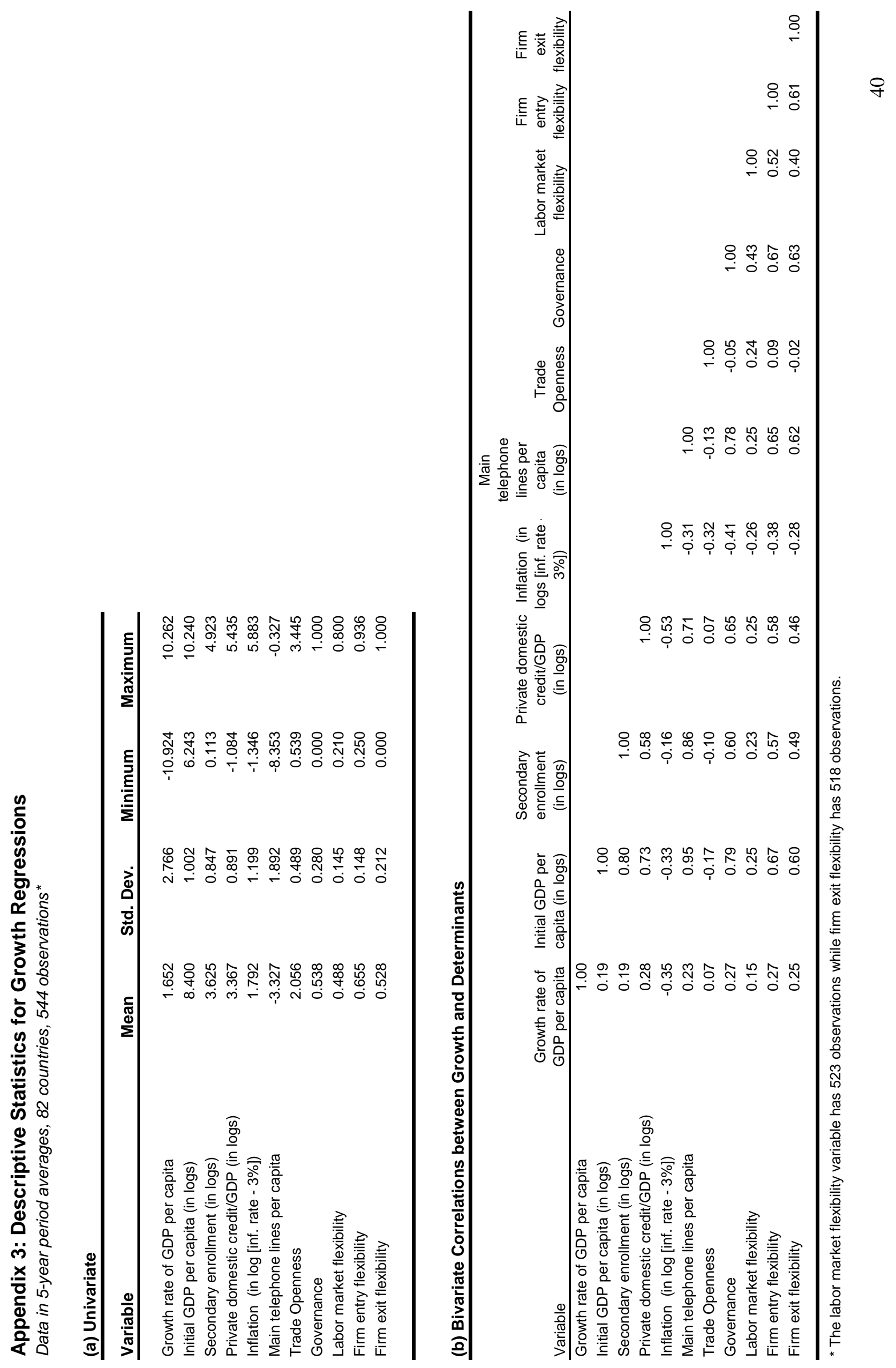

